\title{
INTRODUKSI LAMPU CELUP PADA PENGOPERASIAN JARING INSANG HANYUT
}

\section{Introduction of Underwater Lamp on Drift Gill Net Operations}

\author{
Oleh: \\ Gondo Puspito ${ }^{1 *}$, Sugeng Hartono ${ }^{2}$, Fakhri Kurniawan ${ }^{1}$, Wazir Mawardi ${ }^{1}$ \\ ${ }^{1}$ Departemen Pemanfaatan Sumberdaya Perikanan, Fakultas \\ Perikanan dan Ilmu Kelautan, IPB University, Bogor, Indonesia \\ ${ }^{2}$ Marine Biology Department, Faculty of Marine Science, \\ King Abdulaziz University, Jeddah, Saudi Arabia \\ *Korespondensi penulis: gondo@apps.ipb.ac.id
}

\begin{abstract}
ABSTRAK
Peluang keberhasilan operasi penangkapan ikan dengan jaring insang hanyut sangat ditentukan oleh arah ruaya ikan terhadap posisi jaring. Ikan akan tertangkap jika arah renangnya terhadang oleh jaring. Penelitian mencoba meningkatkan peluang ikan tertangkap dengan memanfaatkan lampu celup. Tujuannya untuk menunjukkan bahwa penggunaan lampu celup akan meningkatkan jumlah ikan hasil tangkapan tanpa mengurangi komposisi jenisnya. Dua unit jaring insang dioperasikan secara bersamaan. Salah satu unit jaring insang dilengkapi dengan lampu celup. Hasil penelitian menunjukkan penggunaan lampu celup tidak mempengaruhi komposisi jenis ikan yang tertangkap, tetapi hanya mempengaruhi jumlah tangkapannya. Jumlah total ikan hasil tangkapan jaring insang yang dilengkapi lampu celup mencapai 3.521 ekor, atau 58,82\% dari seluruh ikan hasil tangkapan, sedangkan jaring insang tanpa lampu celup sebanyak 2.465 ekor $(41,18 \%)$. Rincian hasil tangkapan jaring insang yang dilengkapi lampu celup dan tanpa lampu celup adalah mackerel tuna (Euthynnus affinis) sebanyak 218 ekor dan 129 ekor, spanish mackerel (Scomberomorus commerson) (80; 50), needlefish (Tylosurus crocodilus) (7; 3), Indo-Pacific sailfish (Istiophorus platypterus) (4; 2), driftfish (Psenes cyanophrys) (2.838; 2.051), dan moonfish (Mene maculata) $(374 ; 230)$.
\end{abstract}

Kata kunci: high-brightness LEDs, jaring insang hanyut, komposisi jenis ikan, lampu celup

\begin{abstract}
The probability of successful fishing operations with drift gill nets is largely determined by the direction of the fish distribution to the position of the nets. Fish will be caught if its direction of swimming blocked by the net. This research attempted to increase the chances of fish being caught by using an underwater lamp. The aim is to show that the use of underwater lamp will increase the number of fish caught without reducing the species composition. Two units of gill nets were operated simultaneously. One of the gill net units is equipped with an underwater lamp. The results showed that the use of a underwater lamp did not affect the composition of the type of fish caught, but only affected the number of fish caught. The total number of fish caught by gill nets equipped with underwater lamp was 3,521, or $58.82 \%$ of the total fish caught, while gill nets without underwater lamp were 2,465 (41.18\%). Details of the catches of gill nets equipped with underwater lamp and without underwater lamp are mackerel tuna (Euthynnus affinis) as many as 218 and 129 fish, spanish mackerel (Scomberomorus commerson) (80; 50), needlefish (Tylosurus crocodilus) (7; 3), Indo-Pacific sailfish (Istiophorus platypterus) (4; 2), driftfish (Psenes cyanophrys) (2,838; 2,051), and moonfish (Mene maculata) $(374 ; 230)$.
\end{abstract}

Key words: drift gill net, high-brightness LEDs, species composition, underwater lamp 


\section{PENDAHULUAN}

Jaring insang hanyut tergolong ke dalam kelompok jaring insang. Konstruksinya sangat sederhana, karena hanya terdiri atas 1 lapis jaring. Bagian atas jaring dilengkapi dengan pelampung yang disusun secara berderet pada tali pelampung. Adapun bagian bawahnya diberi beban berupa beberapa pemberat yang juga disusun secara berderet pada tali pemberat. Adanya gaya apung dari pelampung dan gaya tenggelam pemberat menyebabkan jaring akan terentang, baik secara vertikal mau pun horizontal, menyerupai dinding penghadang ketika ditenggelamkan ke dalam air.

Prinsip pengoperasian jaring insang hanyut hanya dilakukan secara pasif dan umumnya pada malam hari. Jaring dibentangkan di dalam air yang merupakan jalur ruaya ikan dan dibiarkan hanyut terbawa arus (Brandt 1984). Sasaran tangkapnya berupa jenis ikan pelagis kecil berukuran antara 5-50 $\mathrm{cm}$, seperti kembung (Rastrelliger sp.), tembang (Sardinella fimbriata), selar (Selar sp.), lemuru (Sardinella sp.), dan layang (Decapterus ruselli) (Nybakken 1992). Seluruh ikan tergolong sebagai jenis ikan nokturnal yang aktif pada malam hari. Menurut Laevastu dan Hayes (1981), ikan pelagis kecil nokturnal akan menyebar secara merata di permukaan air pada malam hari. Sebaliknya pada siang hari, ikan akan beraktivitas pada kedalaman 12-22 $\mathrm{m}$ dari permukaan air untuk menghindari panas matahari yang terlalu tinggi. Beberapa jenis ikan demersal, seperti layur, juga akan melakukan migrasi vertikal ke lapisan atas bercampur dengan ikan pelagis untuk mencari makan pada malam hari.

Keberhasilan operasi penangkapan ikan dengan jaring insang hanyut sangat tergantung pada arah ruaya ikan terhadap posisi jaring. Ikan akan tertangkap jika pergerakannya memotong posisi jaring. Ikan akan menabrak jaring insang dan selanjutnya tersangkut, terjerat, atau terpuntal. Laevastu dan Hayes (1982) menyebutkan bahwa arah renang ikan biasanya melawan arus pada siang hari dan searah arus pada malam hari. Dengan demikian, peluang ikan tertangkap oleh jaring insang hanyut menjadi sangat besar jika jaring terentang sempurna dan posisinya tegak lurus terhadap arus. Salah satu solusi untuk lebih meningkatkan hasil tangkapan jaring insang hanyut adalah memperbaiki metode penangkapannya dengan menggunakan alat bantu pengumpul ikan atau atraktor cahaya berupa lampu. Ikan yang menabrak jaring tidak lagi disebabkan oleh faktor ketidaksengajaan karena lintasan renangnya terhadang oleh jaring, tetapi tertarik mendekati sumber cahaya yang dipasang pada jaring.

Penelitian mencoba memanfaatkan lampu celup LED (light-emitting diode) sebagai atraktor cahaya untuk mengumpulkan ikan. Jenis lampu yang dicelupkan ke dalam air dipilih karena intensitas cahayanya tidak terkurangi akibat pembiasan, penguraian, maupun pembelokan. Adapun LED dikenal memiliki banyak kelebihan dibandingkan dengan jenis lampu lainnya, seperti hemat energi, kokoh, usia pakai yang panjang, dan intensitas cahayanya stabil (Pulli et al. 2015). Penelitian yang sama telah dilakukan sebelumnya oleh Hartono et al. (2019). Perbedaannya terletak pada jumlah lampu yang digunakan sebanyak 3 unit yang masing-masing berisi 2 keping LED COB (chip on board) berdaya 75 watt/keping. Penelitian mencoba menyederhanakan lampu yang digunakan agar mudah ditiru oleh nelayan. Jumlah lampu hanya 1 unit yang dibuat dari lampu penerangan darurat. Tujuan yang ingin didapat dari penelitian adalah penggunaan cahaya pada pengoperasian jaring insang hanyut akan meningkatkan jumlah ikan hasil tangkapan tanpa mengurangi komposisi jenisnya.

Kajian yang membahas penggunaan lampu celup pada jaring insang hanyut untuk meningkatkan hasil tangkapan ikan masih sulit ditemukan. Dua pustaka yang didapat hanya membahas penggunaan lampu celup untuk mengusir penyu agar tidak tertangkap oleh jaring insang hanyut (Wang et al. 2010; Prasetyo et al. 2017) dan bukan untuk meningkatkan hasil tangkapan berupa ikan. Beberapa pustaka berikut yang dianggap mendukung penelitian membahas ketertarikan ikan terhadap cahaya ditulis oleh Urbasa et al. (2015), Nurdin et al. (2007), Natsir dan Mahisworo (2010), dan Baswantara et al. (2020). 


\section{METODE PENELITIAN}

Penelitian dilaksanakan antara bulan Agustus-Oktober 2019 berlokasi di perairan Teluk Palabuhanratu, Sukabumi, Jawa Barat (Gambar 1). Metode yang digunakan adalah metode percobaan dengan mengoperasikan 2 unit jaring insang, masing-masing jaring insang tanpa lampu celup (JTL) dan jaring insang dengan lampu celup (JDL) secara bersamaan. Kedua unit jaring insang dioperasikan sebanyak 10 malam @2 kali ulangan, yaitu antara pukul 19.00-23.00 WIB dan 01.00-05.00 WIB.

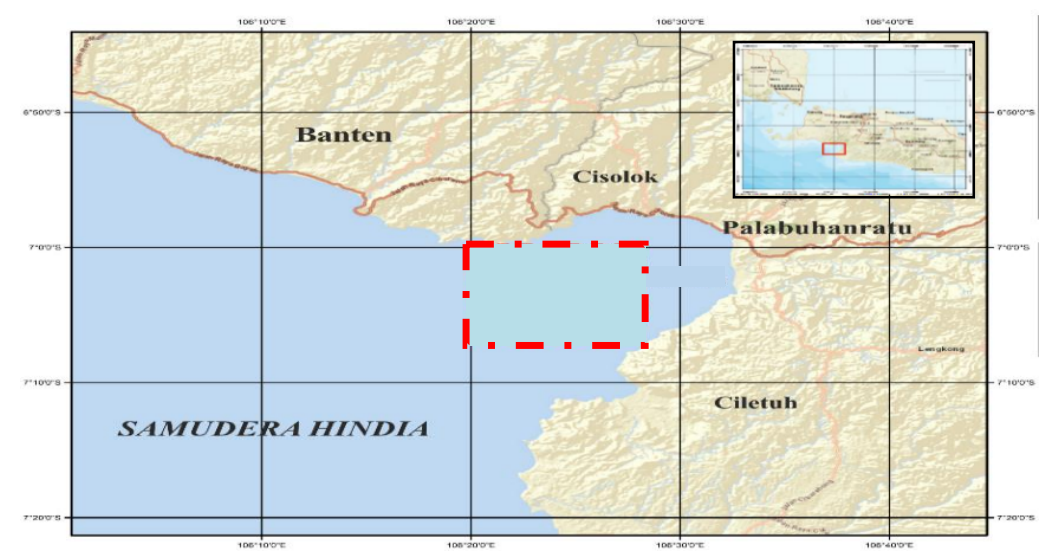

Gambar 1 Lokasi penangkapan ikan

Satu unit jaring insang terdiri atas 10 lembar jaring yang terbuat dari material poliamida multifilamen dengan ukuran mata 4 inci. Ukuran satu lembar jaring $1.200 \times 250(\mathrm{p} \times \mathrm{t})(\mathrm{mata})$, atau 52 $\times 16(\mathrm{p} \times \mathrm{t}) \mathrm{m}$. Dengan demikian, panjang total jaring insang yang dioperasikan, baik dengan atau tanpa lampu, $520 \mathrm{~m}$. Tali ris atas dan tali pelampung terbuat dari material yang sama polietilen multifilamen $\varnothing 0,5 \mathrm{~cm}$. Sebanyak 50 pelampung disusun berderet pada tali pelampung. Jaring tidak dilengkapi tali pemberat dan tali ris bawah. Pemberatnya hanya berupa 2 batu @ 0,5 kg yang diikatkan pada kedua ujung bawah setiap jaring. Sementara lampu celup sebagai alat bantu penangkapannya tersusun atas 2 unit lampu darurat yang dimasukkan ke dalam stoples. Kedua lampu disusun secara paralel dan dihidupkan oleh 2 baterai kering $6 \mathrm{~V}$ yang disusun secara seri, sehingga tegangannya menjadi $12 \mathrm{~V}$. Gambar 2 menunjukkan konstruksi lampu celup LED yang dibuat dari lampu darurat high-brightness LEDs merek 'Krisbow' 5 watt. Jumlah lampu yang dibuat sebanyak 2 unit. Gambar 3 menunjukkan posisi penempatan lampu celup di bagian tengah antara jaring kelima dan keenam.

Kedua unit jaring insang dioperasikan secara bersamaan pada lokasi perairan yang sama dengan kapal yang berbeda sebanyak 20 ulangan. Posisi kedua unit jaring berjarak sekitar 1 mil. Adapun metode pengoperasiannya disesuaikan dengan kebiasaan nelayan, yaitu:

1. Kapal bergerak memotong arus sambil menebarkan jaring;

2. Jaring diangkat ke atas kapal setelah didiamkan selama 4 jam; dan

3. Proses penangkapan dilakukan kembali pada lokasi berbeda menggunakan lampu celup berbeda.

Penetapan jumlah operasi penangkapan ikan sebanyak 20 ulangan didasarkan atas persamaan Federer (1963), yaitu (t-1) $(n-1) \geq 15$. Konstanta $t$ adalah jumlah perlakuan dan $n$ ulangan. Penelitian hanya menggunakan $t=2$ perlakuan. Oleh karenanya, operasi penangkapan harus dilakukan sedikitnya sebanyak 16 ulangan. 


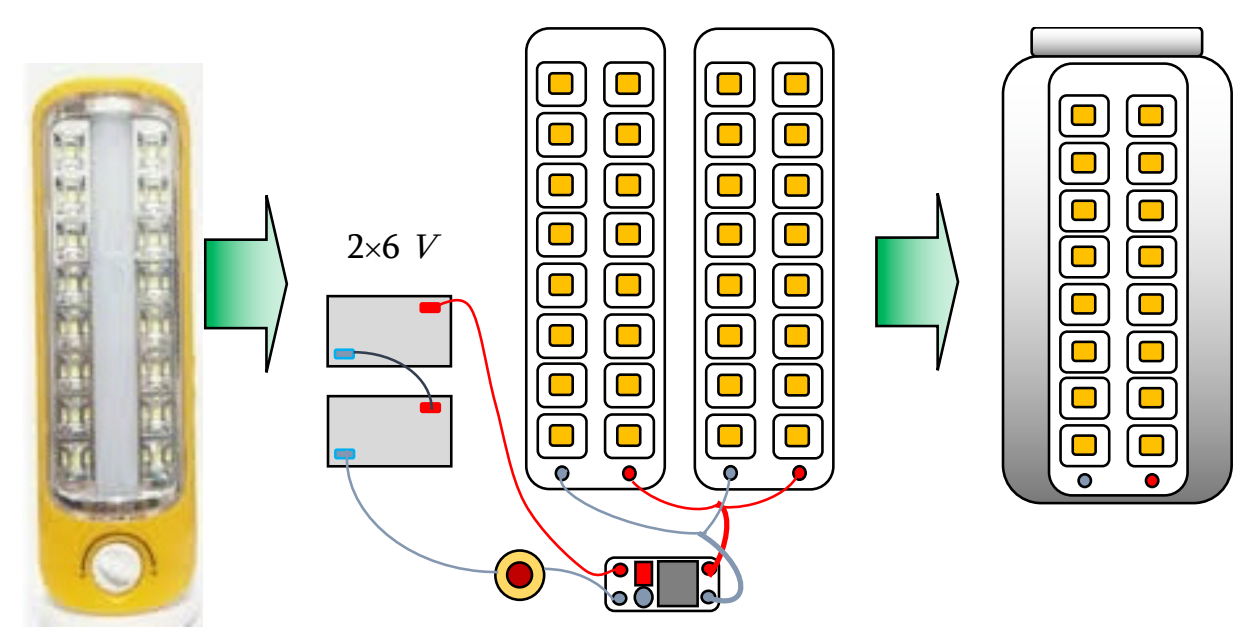

Gambar 2 Konstruksi lampu celup LED

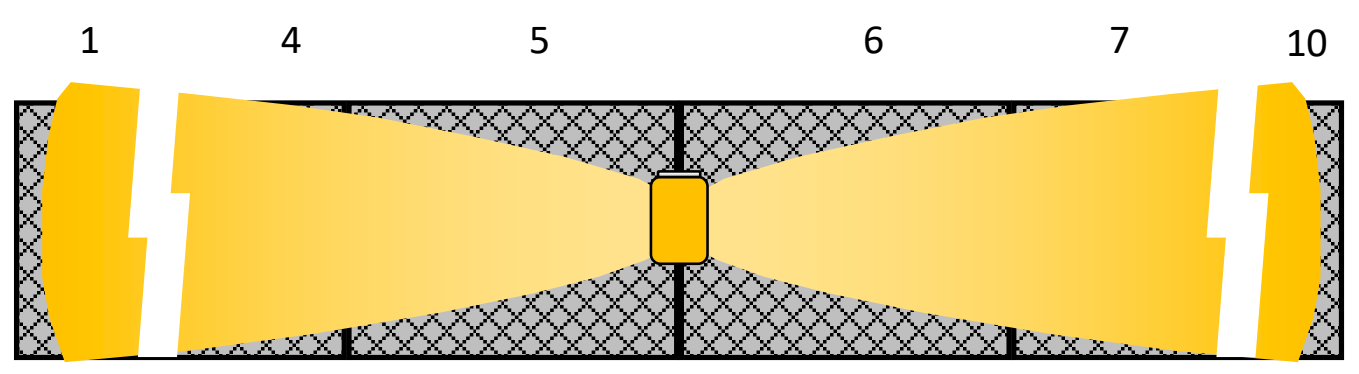

Gambar 3 Ilustrasi posisi lampu celup LED pada jaring insang hanyut

Data hasil tangkapan dianalisis secara deskriptif dan statistik. Analisis deskriptif ditujukan untuk melihat perbedaan komposisi jenis hasil tangkapan antara jaring insang JTL dan JDL. Sementara uji statistik digunakan untuk membuktikan apakah penggunaan lampu celup dapat meningkatkan jumlah hasil tangkapan. Urutan uji statistik dimulai dengan menentukan apakah data menyebar normal atau tidak normal melalui uji kenormalan Kolmogorov-Smirnov. Selanjutnya, uji statistik parametrik T-test dilakukan apabila data menyebar normal. Jika data tidak menyebar normal, maka uji statistik non parametrik Mann-Whitney digunakan untuk menguji hipotesis apakah penggunaan lampu celup mempengaruhi hasil tangkapan jaring insang. Salah satu dari 2 keputusan yang diambil adalah:

1. Apabila nilai Asymp Sig. (2-tailed) < ( $\alpha)$, maka tolak H0. Artinya adalah hasil tangkapan JDL memiliki perbedaan yang signifikan dengan hasil tangkapan JTL; dan

2. Apabila nilai Asymp Sig. (2-tailed $)>(\alpha)$, maka gagal tolak H0. Artinya adalah hasil tangkapan JDL tidak memiliki perbedaan yang signifikan dengan hasil tangkapan JTL.

Adapun hipotesis atau kesimpulan yang diambil adalah 1. H0: Tidak ada perbedaan hasil tangkapan antara JDL dan JTL, atau H1: Ada perbedaan hasil tangkapan antara JDL dan JTL. Analisis dilakukan pada taraf $(\alpha)=0,05$ (Supangat 2007 dan Sugiyono 2015).

\section{HASIL DAN PEMBAHASAN}

\section{Performa Jaring Insang}

Posisi jaring insang hanyut ideal ketika dioperasikan adalah tegak lurus terhadap arus (Gambar 4a). Jaring membentang sempurna menyerupai dinding penghadang dengan panjang dan tinggi sesuai dengan rancangan. Peluang ikan menabrak jaring menjadi sangat besar. Ukuran target tangkapan otomatis akan sesuai dengan ukuran dan bukaan mata jaring yang telah ditentukan sebelumnya. 
Kenyataannya, jaring insang sangat sulit dibentangkan secara sempurna di dalam air, karena sangat dipengaruhi oleh gaya eksternal dan internal yang bekerja pada jaring. Penebaran jaring secara tidak bersamaan menyebabkan jaring yang lebih dulu diturunkan akan mendapatkan gaya eksternal dari tekanan arus. Akibatnya, posisi keseluruhan jaring membentuk sudut terhadap arah arus. Menurut Stewart dan Ferro (1985), gaya eksternal lebih disebabkan oleh tekanan arus yang menyebabkan posisi jaring membentuk sudut terhadap arah arus. Adapun gaya internal bersumber dari beberapa bagian alat tangkap (Fridman 1986), misalnya tali-temali yang memendek ketika dilepaskan ke dalam air, akan menyebabkan jaring juga ikut memendek (Gambar $4 \mathrm{~b}$ ). Penampang frontal jaring secara horizontal yang berkurang terhadap arus-atau arah renang ikan -- akan menurunkan peluang ikan tertangkap dalam jumlah banyak.

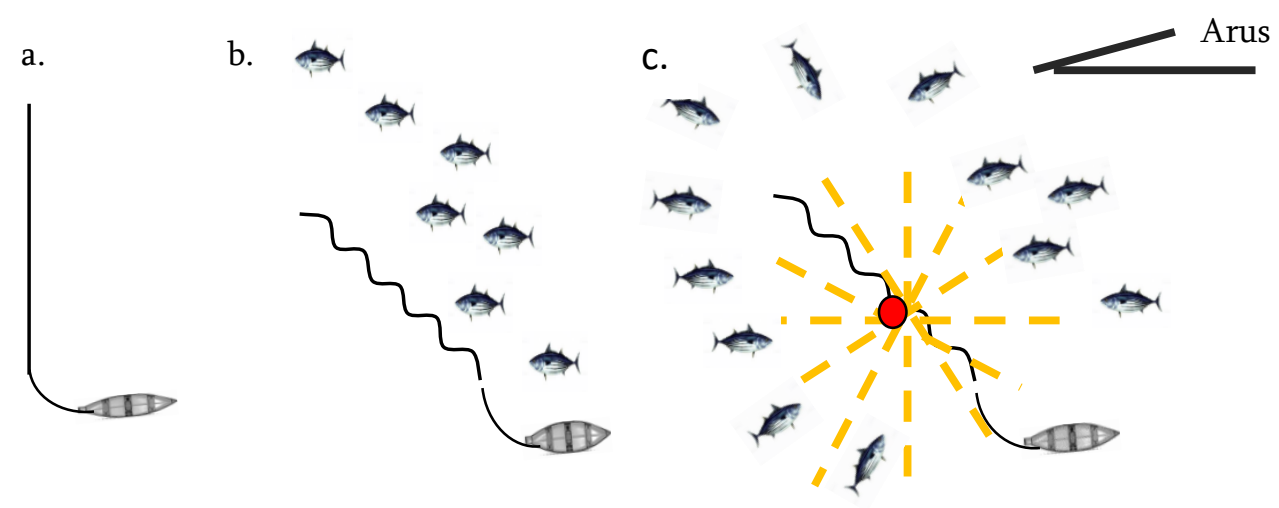

Gambar 4 Ilustrasi tampilan atas jaring insang (a). ideal, (b). sebenarnya, dan (c). dilengkapi lampu celup.

Penggunaan lampu celup menyebabkan pengaruh gaya internal dan eksternal yang bekerja pada jaring insang menjadi relatif tidak begitu berarti. Pemasangan jaring memotong secara tegak lurus terhadap arah arus sudah tidak terlalu diperhitungkan. Ikan akan datang dengan sendirinya mendekati jaring (Gambar 4c). Cahaya merupakan indikator ketersediaan makanan bagi jenis-jenis ikan yang mencari makan pada malam hari (Bouman et al. 2003).

\section{Komposisi Hasil Tangkapan}

Hasil tangkapan jaring insang dikelompokkan atas jenis ikan pelagis sebagai hasil tangkapan utama dan ikan demersal atau hasil tangkapan sampingan. Empat jenis ikan pelagis yang tertangkap oleh jaring insang terdiri atas tongkol (Euthynnus affinis), tenggiri (Scomberomorus commerson), cendro (Tylosurus crocodilus), dan layaran (Istiophorus platypterus). Adapun 2 jenis ikan demersal yang juga terjaring meliputi gelang sadap/driftfish (Psenes cyanophrys) dan semar (Mene maculata). Jumlah total ikan hasil tangkapan jaring insang mencapai 5.986 ekor, atau seberat $1.881,85 \mathrm{~kg}$. Ikan demersal mendominasi hasil tangkapan jaring insang. Jumlahnya mencapai 5.493 ekor, atau $91,76 \%$ dari seluruh jumlah tangkapan dengan berat 1.157,42 kg (61,5\%). Rincian komposisi jumlah dan berat untuk setiap jenis ikan hasil tangkapan dijelaskan pada Gambar 5. 


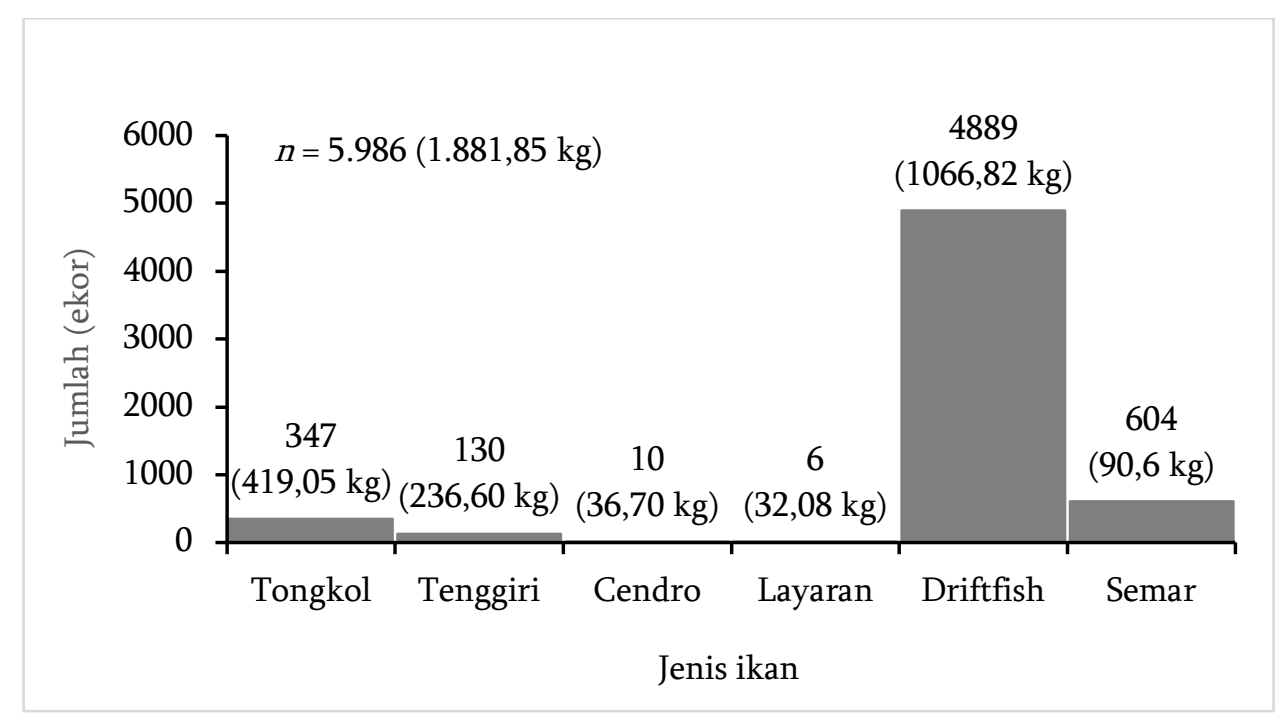

Gambar 5 Komposisi jumlah dan berat hasil tangkapan jaring insang per jenis ikan

Keempat ikan pelagis sebenarnya bersifat diurnal atau aktif pada siang hari, tetapi tertangkap oleh jaring insang hanyut yang dioperasikan pada malam hari. Matsumoto et al. (1984) menyebutkan bahwa ikan pelagis umumnya aktif melakukan pemangsaan menjelang matahari terbit dan pada saat matahari akan terbenam. Jenis tenggiri, menurut Ward dan Myers (2005), akan terkonsentrasi di permukaan air selama siang hari dan kemudian mulai bergerak menyebar di permukaan air untuk mencari makan di malam hari. Tongkol mendominasi jenis ikan pelagis hasil tangkapan jaring insang. Jumlahnya mencapai 347 ekor, atau 70,39\% dari seluruh ikan pelagis yang tertangkap. Penyebab utamanya adalah musim penangkapan tongkol di Samudera India berlangsung antara bulan Mei-Juni dan Oktober-Desember (Abdussamad et al. (2012). Salah satunya bersesuaian dengan waktu pengoperasian jaring insang antara bulan Agustus-Oktober. Tenggiri berada di urutan kedua sebanyak 130 ekor (26,37\%). Jumlahnya tidak terlalu banyak, karena penangkapannya hanya dilakukan pada awal musim yang berlangsung antara April-Juli dan September-November (Nikijuluw 2009). Menurutnya, peluang tenggiri tertangkap oleh jaring insang sangat besar, karena jalur migrasinya hanya di sekitar perairan pantai. Namun demikian, jumlah tenggiri yang dapat ditangkap sangat kecil, karena tenggiri dewasa umumnya hanya membentuk gerombolan kecil. Sementara 2 jenis ikan pelagis lainnya, yaitu cendro dan layaran tertangkap dalam jumlah yang sangat sedikit, masing-masing 10 ekor $(2,03 \%)$ dan 6 ekor $(1,22 \%)$. Kedua jenis ikan cenderung soliter dan pergerakannya sangat gesit, sehingga peluang tertangkapnya oleh jaring insang sangat kecil (Genisa 1999). Cendro, menurut Agustina et al. (2016), hidup di perairan lepas pantai dan puncak musimnya terjadi pada bulan April. Hidupnya soliter dan pergerakannya sangat gesit sehingga sangat sulit ditangkap dalam jumlah yang banyak (Luasunaung dan Reppie 2016). Genisa (1999) menambahkan bahwa layaran hidup di perairan laut dalam dan sesekali muncul ke permukaan perairan. Musim puncak penangkapannya terjadi pada bulan April (Widodo et al. 2012).

Jenis ikan demersal yang tertangkap dalam jumlah banyak adalah gelang sadap/driftfish, yaitu 4.889 ekor, atau $89 \%$ dari seluruh ikan demersal atau $81,67 \%$ dari seluruh ikan hasil tangkapan. Selanjutnya, semar berada di urutan berikutnya sebanyak 604 ekor (11\%). Menurut Gooding dan Magnuson (1967), gelang sadap/driftfish hidup bergerombol pada kedalaman 15-200 m dan terjangkau oleh pengoperasian jaring insang. Migrasinya dilakukan secara vertikal ke permukaan laut untuk mencari makan (Maherung et al. 2018). Adapun semar jumlahnya sangat sedikit jika dibandingkan dengan gelang sadap/driftfish. Menurut Fadika et al. (2014), musim puncak penangkapan semar hanya berlangsung selama musim peralihan antara Maret-Mei. Pengoperasian jaring insang pada bulan Agustus-Oktober tidak akan menghasilkan jumlah tangkapan yang banyak. 


\section{Pengaruh Penggunaan Lampu Celup terhadap Komposisi Ikan Hasil Tangkapan}

Pengoperasian jaring insang, baik dilengkapi (JDL) atau tidak dilengkapi lampu celup (JTL), mendapatkan komposisi jenis ikan hasil tangkapan yang sama, yaitu hanya terdiri atas 4 jenis ikan pelagis dan 2 jenis ikan demersal. Kelompok ikan pelagis meliputi tongkol, tenggiri, cendro, dan layaran. Adapun kelompok ikan demersal berupa gelang sadap/driftfish dan semar. Gambar 6 mempresentasikan komposisi jumlah ikan hasil tangkapan jaring insang yang dilengkapi dan tanpa lampu celup. Perbedaan hasil tangkapan terlihat jelas pada komposisi jumlah dan berat. Pembahasan difokuskan pada komposisi jumlah, karena hampir seluruh ikan tangkapan berukuran relatif sama, dapat dihitung, dan diidentifikasi dengan mudah.

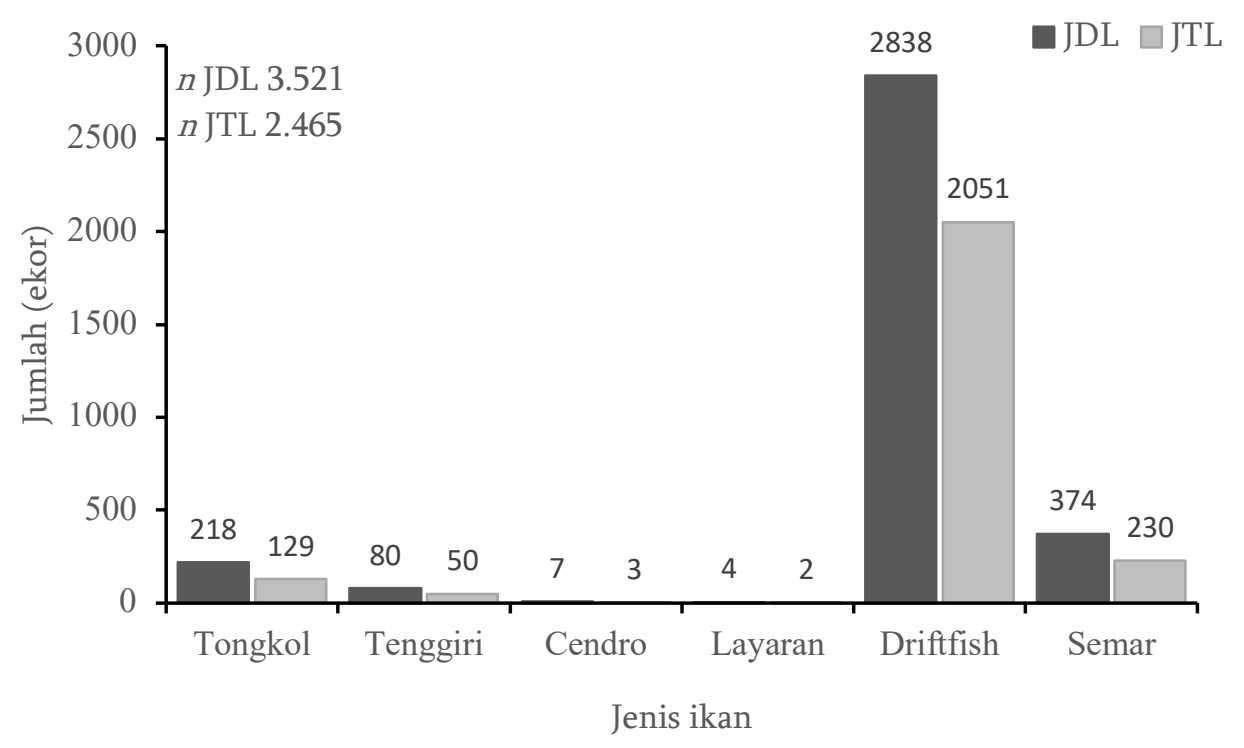

Gambar 6 Komposisi jumlah ikan hasil tangkapan jaring insang dengan dan tanpa lampu celup

Pengoperasian JDL mendapatkan 3.521 ikan, atau 58,82\% dari seluruh ikan hasil tangkapan. Adapun JTL menghasilkan 2.465 ikan (41,18\%). Berdasarkan uji statistik kenormalan KolmogorovSmirnov diperoleh hasil bahwa data hasil tangkapan JDL dan JTL tidak menyebar normal. Selanjutnya, hasil kalkulasi memakai uji statistik non parametrik Mann Whitney diperoleh signifikansi 0,014, atau lebih kecil dari Ftabel = 0,05. Kesimpulannya adalah JDL lebih baik dibandingkan dengan JTL, karena jumlah hasil tangkapannya lebih banyak, atau Ho ditolak.

Pengelompokan berdasarkan jenis ikan menempatkan JDL sebagai penangkap ikan demersal terbanyak, yaitu 3.212 ekor atau 91,22\% dari seluruh ikan tangkapan JDL dan pelagis 309 ikan (8,78\%). Sementara JTL menjerat 2.281 ikan demersal, atau 92,54\% dari seluruh ikah hasil tangkapan JTL dan 184 ikan pelagis (7,46\%). Tiga jenis hasil tangkapan terbanyak JDL dan JTL adalah sama. Urutannya adalah gelang sadap/driftfish (2.297 ikan; 541 ikan), semar (304 ikan; 70 ikan), dan tongkol (183 ikan; 35 ikan).

Jumlah ikan hasil tangkapan JTL lebih sedikit dari JDL karena hanya mengandalkan penghadangan terhadap ruaya horizontal ikan pelagis dan pergerakan ikan demersal yang beruaya vertikal. Pemasangan jaring insang di permukaan air sangat memungkinkan ikan-ikan yang beruaya dekat dengan permukaan air atau di permukaan air akan menabrak dan tertangkap oleh jaring. Jenis ikan pelagis, seperti tongkol, menurut Tangke dan Deni (2013); Shabrina et al. (2017), tergolong ke dalam kelompok ikan pelagis yang hidup di permukaan air hingga mencapai kedalaman $40 \mathrm{~m}$. Ruaya tongkol cenderung mengikuti pergerakan arus (Kuswanto et al. 2017). Tenggiri merupakan jenis ikan pelagis yang beruaya di dekat permukaan air berarus dalam bentuk kelompok kecil tidak jauh dari pantai (Tangke 2012). Cendro berenang di lapisan permukaan air dan ruayanya di sepanjang perairan 
pantai yang berbatasan dengan laut dalam, terutama perairan Indonesia bagian timur, selatan Jawa, barat Sumatera, dan Selat Sunda (Luasunaung dan Reppie 2016). Adapun layaran sebenarnya tergolong sebagai jenis ikan predator laut dalam dan sering muncul ke permukaan air (Alwi dan Muhammad 2019; Genisa 1999). Suman et al. (2016) menambahkan bahwa layaran dikelompokkan sebagai ikan pelagis besar yang lebih bersifat oseanik, atau beruaya sangat jauh melampaui yurisdiksi suatu negara. Sementara jenis ikan demersal berupa gelang sadap/driftfish merupakan ikan yang hidup bergerombol di lingkungan bentopelagik, atau mulai dari dasar hingga permukaan perairan pada kedalaman antara 15-200 m (Gooding dan Magnuson, 1967). Adapun semar, menurut Pangalila et al. (2014), memiliki habitat di perairan pesisir yang relatif dalam hingga $200 \mathrm{~m}$. Semar melakukan migrasi vertikal harian untuk mencari makan, sehingga memungkinkan tertangkap oleh jaring insang. Ashari et al. (2014) menjelaskan bahwa semar melakukan migrasi vertikal harian untuk mencari makan sehingga memungkinkan tertangkap oleh jaring insang.

Penggunaan atraktor cahaya berupa lampu celup mengubah prinsip pengoperasian jaring insang hanyut. Cahaya merupakan indikator adanya makanan bagi organisme laut (Kadir et al. 2019). Cahaya akan membuat zooplankton mudah mendeteksi keberadaan fitoplankton yang menjadi makanannya. Keberadaan zooplankton akan mengundang ikan-ikan kecil dan diikuti oleh gelang sadap/driftfish dan semar untuk mempredasinya. Selanjutnya, ikan-ikan pelagis besar, seperti tongkol dan tenggiri, yang beruaya tepat melintasi atau di sekitar susunan jaring akan mendekati atraktor cahaya untuk memakan ikan pelagis kecil (Puspito et al. 2017). Siklus saling memakan antara ikan-ikan kecil dengan ikan-ikan besar akan memunculkan adanya rantai makanan.

Gelang sadap/driftfish tergolong sebagai karnivora yang memakan ikan-ikan berukuran lebih kecil yang berada di sekitar sumber cahaya (Venu dan Kurup 2006). Nikonorov dan Nikonorov (1975) menegaskan bahwa cahaya lampu merangsang ikan untuk melakukan aktivitas pemangsaan terhadap ikan-ikan kecil yang berada di sekeliling atraktor cahaya. Secara ekologis, keberadaan gelang sadap/driftfish sangat berpengaruh terhadap rantai makanan (Sharif 2018) dan berkaitan dengan kemunculan ikan karnivora yang menjadi pemangsanya (Effendie 1997). Semar juga memiliki tingkah laku yang mirif dengan gelang sadap/driftfish. Ketertarikannya terhadap cahaya lebih disebabkan oleh adanya makanannya berupa plankton dan ikan-ikan yang berukuran lebih kecil (Pangalila et al. 2014; Ashari et al. 2014).

Ikan tongkol akan berdistribusi pada perairan yang suhunya hangat dan banyak mengandung fitoplankton dan zooplankton untuk memangsa ikan-ikan kecil. Keberadaan ikan-ikan berukuran kecil akan mengundang jenis-jenis ikan predator buas lain, seperti tengggiri (Kuswanto et al. 2017), cendro (Tangke 2012; Luasunaung 2016) dan layaran (Sangkoy et al. 2020).

\section{KESIMPULAN DAN SARAN}

Pengoperasian jaring insang, baik menggunakan (JDL) atau pun tidak menggunakan lampu celup (JTL), menghasilkan jenis ikan yang sama, yaitu tongkol (Euthynnus affinis), tenggiri (Scomberomorus commerson), cendro (Tylosurus crocodilus), layaran (Istiophorus platypterus), gelang sadap/driftfish (Psenes cyanophrys), dan semar (Mene maculata). Perbedaanya terdapat pada jumlah ikan hasil tangkapan jaring insang yang dilengkapi lampu celup (JDL) mencapai 3.521 ekor, atau 58,82\% dari seluruh ikan hasil tangkapan, sedangkan jaring insang tanpa lampu celup JTL 2.465 ekor $(41,18 \%)$. Rincian hasil tangkapan jaring insang yang dilengkapi lampu celup dan tanpa lampu celup adalah tongkol (Euthynnus affinis) sebanyak 218 ekor dan 129 ekor, tenggiri (Scomberomorus commerson) (80; 50), cendro (Tylosurus crocodilus) (7; 3), layaran (Istiophorus platypterus) (4; 2), gelang sadap/driftfish (Psenes cyanophrys) (2.838; 2.051), dan semar (Mene maculata) (374; 230). 


\section{DAFTAR PUSTAKA}

Abdussamad, E. M., Rohit, P., Koya, K. P. S., \& Sivadas, M. 2012. Status and Potential of Neritic Tunas Exploited from Indian Waters. Penang, Malaysia: IOTC Second Working Party on Neritic Tunas.

Agustina, S., Irmawati, R., \& Susanto, A. 2016. Musim Penangkapan Ikan Pelagis Besar di Pelabuhan Perikanan Pantai Lempasing Provinsi Lampung. Jurnal Perikanan dan Kelautan 6(1): 74-82.

Alwi, D., Muhammad, S. H. 2019. Pengaruh Perbedaan Umpan Buatan (Artificial Bait) terhadap Hasil Tangkapan dengan Pancing Coping (Hand Line) di Perairan Desa Daeo Majiko Kabupaten Pulau Morotai. Jurnal Ilmu kelautan Kepulauan 2 (2): 23-31.

Ashari, F., Redjeki, S., \& Kunarso. 2014. Keterkaitan Jumlah Tangkapan Ikan Pelagis Kecil dengan Distribusi Klorofil-a dan Suhu Permukaan Laut Menggunakan Citra Satelit Modis di Laut Jawa dan Selat Makassar. Journal of Marine Research 3(3): 366- 373.

Baswantara, A., Firdaus, A. N., Astiyani, W. P., Jaya, I., \& Yusfiandayani, R. 2020. Respon Ikan dan Hasil Tangkapan Berdasarkan Perbedaan Kombinasi Warna Cahaya LED sebagai Atraktor. Jurnal Penelitian Perikanan Indonesia 26(3): 181-188.

Bouman, H. A., Platt, T., Sathyendranath, S., Li, W. K. W., Stuart, V., Fuentes-Yaco, C., Maass, H., Horne, E. P. W., Ulloa, O., Lutz, V., \& Kyewalyanga, M. 2003. Temperature as Indicator of Optical Properties and Community Structure of Marine Phytoplankton: Implications for remote sensing. Marine Ecology Progress Series 258:19-30.

Brandt, V. A. 1984. Fish Catching Methods of The World. Fishing News Book Ltd. London.

Effendie, M. I. 1997. Biologi Perikanan. Yayasan Pustaka Nusatama. Yogyakarta.

Fadika, U., Rifai A., \& Rochaddi, B. 2014. Arah dan Kecepatan Angin Musiman serta Kaitannya dengan Sebaran Suhu Permukaan Laut di Selatan Pangandaran Jawa Barat. Jurnal Oseanografi 3(3): 429 -437 .

Federer, W. T. 1963. Experimental Design: Theory and Application. Oxford \& IBH Publishing Co. New Delhi.

Fridman, A. L. 1986. Calculations for Fishing Gear Designs. Fishing News Books. Farnham, Surrey.

Genisa, A. S. 1999. Pengenalan Jenis - jenis Ikan Laut Ekonomis Penting di Indonesia. Oseana 14(1): 17-38.

Gooding, R. M., \& Magnuson, J. J. 1967. Ecological significance of a drifting object to pelagic fishes. Jurnal Pacific Science 21: 486-497.

Hartono, A., Puspito, G., \& Mawardi, W. 2019. Uji Coba Lampu Celup LED pada Jaring Insang sebagai Upaya Meningkatkan Hasil Tangkapan. Jurnal Teknologi Perikanan dan Kelautan 10 (1): 15-26.

Kadir, I. A., Susanto, A. N., A Karman, IO Ane. 2019. Status Keberlanjutan Perikanan Bagan Perahu Berbasis Bio-ekonomi di Desa Toniku Kabupaten Halmahera Barat. Jurnal Ilmu dan Teknologi Kelautan Tropis 11(1): 181-190.

Kuswanto, T. D., Syamsuddin, M. L., \& Sunarto. 2017. Hubungan Suhu Permukaan Laut dan Klorofila terhadap Hasil Tangkapan Ikan Tongkol di Teluk Lampung. Jurnal Perikanan dan Kelautan 8(2): 90-102.

Laevastu, T., \& Hayes, M. L. 1981. Fisheries Oceanography and Ecology. Fishing News Books. Farnham. 
Luasunaung, A., \& Reppie, E. 2016. Umpan Buatan dan Pengaruhnya terhadap Hasil Tangkapan Pancing Layang-layang di Selat Bangka, Sulawesi Utara. Marine Fisheries 7(2): 117-123.

Maherung, S., Bataragoa, N. E., Salaki, M. S. 2018. Ukuran dan Kebiasaan Makan Ikan Kuwe (Caranx spp) di Daerah Intertidal Sekitar Laboratorium Basah FPIK - Unsrat Likupang. Jurnal Ilmiah Platax 6 (1): 6-11.

Matsumoto, W.M., Skillman, R.A. and Dizon, A.E., 1984. Synopsis of biological data on skipjack tuna, Katsuwonus pelamis (No. 136). National Oceanic and Atmospheric Administration, National Marine Fisheries Services.

Matsumoto, W. M., \& Skillman, R. A., \& Dizon, A. E. 1984. Synopsis of Biological Data on Skipjack Tuna, Katsuwonus pelamis. National Oceanic and Atmospheric Administration, National Marine Fiheries Services.

Natsir, M., \& Mahiswara. 2010. Pola Agregasi Ikan Pelagis terhadap Pengaruh Cahaya pada Alat Tangkap Mini Purse Seine. Jurnal Ilmu dan Teknologi Perikanan Tangkap 16(1): 63-73.

Nikonorov, I. V., \& Nikonorov, I. V. E. 1975. Interaction of Fishing Gear with Fish Aggregations. Israeli Program for Scientific Translations. Jerussalem.

Nikijuluw, V. P. H. 2009. Status Sumber Daya Ikan Tuna Samudera Hindia: Implikasinya Bagi Indonesia. Jurnal Kebijakan Perikanan Indonesia 1(1) : 31-44.

Nurdin, E., Natsir, M., \& Hufiadi. 2007. Pengaruh Intensitas Cahaya terhadap Ketertarikan Gerombolan Ikan Pelagis Kecil pada Mini Purse Seine di Perairan Pemalang Jawa Tengah. Jurnal Ilmu dan Teknologi Perikanan Tangkap 13(2): 125-132.

Nybakken, J. W. 1992. Biologi Laut: Suatu Pendekatan Ekologis. Diterjemahkan oleh HM Eidman, Koesoebiono, DG Bengen, M. Hutomo dan S Subarjo. PT. Gramedia Pustaka Utama. Jakarta.

Pangalila, F. P. T., Budiman, J., Telleng, A. T. R., \& Reppie, E. 2014. Kajian Perikanan Tangkap Mene maculata di Teluk Buyat. Jurnal IPTEKS PSP 1(2): 103-111.

Prasetyo, G. D., Wahju, R. I., Yusfiandayani, R., \& Riyanto, M. 2017. Light Emitting Diode (LED) Hijau dan Pengaruhnya terhadap Pengurangan Bycatch Penyu pada Perikanan Gillnet di Perairan Paloh. Marine Fisheries 8 (1): 87-99.

Pulli, T., Dönsberg, T., Poikonen, T., Manoocheri, F., Ka'rha, P., \& Ikonen, E. 2015. Advantages of white LED Lamps and New Detector Technology in Photometry. Light: Science \& Applications 4-e332: 1-7.

Puspito, G., Ahmad, S., \& Sururi, M. 2017. Selection of Lamp Reflector Construction and Fishing Time of Lift Net. Egyptian Journal of Aquatic Research 43: 155-160.

Sangkoy, R., Labaro, I. L., \& Paransa, I. J., 2020. Kajian Operasi Penangkapan Pancing Ulur Pelagis Besar yang Menggunakan Umpan Hidup. Jurnal Ilmu dan Teknologi Perikanan Tangkap 5(1): 30-34.

Shabrina, N. N., Sunarto, Hamdani, H. 2017. Penentuan Daerah Penangkapan Ikan Tongkol Berdasarkan Pendekatan Distribusi Suhu Permukaan Laut dan Hasil Tangkapan Ikan di Perairan Utara Indramayu Jawa Barat. Jurnal Perikanan dan Kelautan 8(1): 139-145.

Sharif, T. A., Yonvitner, \& Fahrudin, A. 2018. Biologi Reproduksi Ikan Peperek (Gazza minuta Bloch, 1795) yang Didaratkan di PPN Palabuhanratu, Sukabumi, Jawa Barat. Journal of Tropical Fisheries 2(2): 1-8.

Stewart, P. A. M., \& Ferro, R. S. T. 1985. Measurements on Gill Nets in a Flume Tank. Fisheries Research 3: 29-46. 
Sugiyono. 2015. Statistika untuk Penelitian. Alfabeta Bandung. Bandung.

Suman, A., Irianto, H. E., Satria, F., \& Amri, K. 2016. Potensi dan Tingkat Pemanfaatan Sumber Daya Ikan di Wilayah Pengelolaan Perikanan Negara Republik Indonesia (WPP NRI) Tahun 2015 serta Opsi Pengelolaannya. Jurnal Kebijakan Perikanan Indonesia 8(2): 97-110.

Supangat, A. 2007. Statistika : Dalam Kajian Deskriptif, Inferensi, dan Nonparametrik. Prenada Media Group. Jakarta.

Tangke, U. 2012. Analisis Hubungan Faktor Oseanografi dengan Hasil Tangkapan Ikan Tenggiri (Scomberamorus spp.) di Perairan Kec. Leihitu Kab. Maluku Tengah. Jurnal Ilmiah Agribisnis dan Perikanan (Agrikan UMMU-Ternate) 5(2): 1-11.

Tangke, U., \& Deni, S. 2013. Pemetaan Daerah Penangkapan Ikan Madidihang (Thunnus albacares) dan Ikan Cakalang (Katsuwonus pelamis) di Perairan Maluku Utara. Jurnal Ilmiah agribisnis dan Perikanan 6: 1-17.

Urbasa, F., Kaparang, F. E., \& Kumajas, H. J. 2015. Studi Ketertarikan Ikan di Keramba Jaring Apung terhadap Warna Cahaya Lampu di Perairan Sindulang I, Kecamatan Tuminting, Kota Manado. Jurnal Ilmu dan Teknologi Perikanan Tangkap 2 (Edisi Khusus): 39-43.

Venu, S., \& Kurup, B. M. 2006. Distribution and Biology of Deep-sea Fishes Neoepinnulaorientalis Gilchrist and Von Bonde 1924 and Psenes squamiceps Lloyd, 1909 from West Coast of Indian EEZ. Journal of the Marine Biological Associationof India 48 (1): 24 - 28.

Wang, J. H., Fisler, S., \& Swimmer, Y. 2010. Developing Visual Deterrents to Reduce Sea Turtle Bycatch in Gill Net Fisheries. Marine Ecology Progress Series 408: 241-250.

Ward, P., \& Myers, R. A. 2005. Inferring The Depth Distribution of Catchability for Pelagic Fishes and Correcting for Variations in The Depth of Longline Fishing Gear. Canada Journal of Fisheries Aquatic Science 62: 1130-1142.

Widodo, A. A., Satria, F., \& Nugraha, B. 2012. Size and Fishing Ground of Wahoo (Acanthocybium solandri) from Catch Data of Tuna Longline Operated in Indian Ocean. Indonesian Fisheries Research Journal 18 (2): 101-106. 